УДК 821.161 .1

\title{
Л.В. Гармаш
}

\section{ЭРОТИЧЕСКИЕ ЖЕСТЫ В ПОЭЗИИ И ЛИТЕРАТУРНЫХ СИМФОНИЯХ АНДРЕЯ БЕЛОГО: ОТ «ЗОЛОТА В ЛАЗУРИ» К «КУБКУ МЕТЕЛЕЙ»}

Андрей Белый продолжает оставаться одной из самых противоречивых фигур русского модернизма. Его творческое наследие до сих пор оценивается неоднозначно, вызывая бурные споры и никого не оставляя равнодушным.

Созданные специфическими для литературы средствами, т.е. не возникшие как телесная реакция человека, воспринимаемая как непосредственная данность, а полученные описательным путем через посредство слова, паравербальные средства коммуникации всегда выступают в роли значимого элемента текста как художественной системы, так как язык литературного произведения принципиально отличается от естественного языка, на что неоднократно обращали внимание такие ученые, как А. А. Потебня, В. В. Виноградов, А. Р. Арутюнян и др. Поэтому в произведении искусства жест и мимика - «это преднамеренно творимый литературно-стилистический приём» [11].

Несмотря на то что к рассмотрению семантики жеста в творчестве Андрея Белого уже обращались исследователи (Т. Ланген, О. Н. Масленникова, М. Спивак и др.), этот вопрос все еще остается открытым. В системе координат символистского мировосприятия особыми смыслами наделялась одухотворенная телесность. Поэзия Белого и его ранняя симфоническая проза проникнуты напряженным эротизмом, во многом оформившимся под влиянием философских идей Вл. Соловьева, в частности, его трактата «Смысл любви».

В работе предпринят анализ эротических жестов в лирике и в симфониях Андрея Белого как структурно значимых элементов художественного текста. Эротические жесты рассмотрены в контексте творчества писателя, установлены корреляты между жестом как (C) Л.В. Гармаш, 2019

http://dx.doi.org/10.34142/2312-1076.2019.1-2.91-92.04 
32 Наукові записки ХНПУ ім. Г.С. Сковороди. Літературознавство, 2019, вип. 1 - 2 (91 - 92)

поэтическим приемом и мировоззренческими установками автора «Золота в лазури».

Что же такое «жест»? Этимологически это слово восходит через французское geste к латинскому gestus - «действие» [15, с. 50]. Не задаваясь вопросом, что первично - действие (жест) или речь (хотя, как известно, «в начале было слово» (Ин. 1; 1)), подчеркнем существующую между ними неразрывную связь, на что обратил внимание младший современник поэта Ю. Н. Тынянов, полагавший, что «за речью чувствуются жесты, за жестами облик, почти осязаемый, но эта осязаемость неуловима, она сосредоточена в речевой артикуляции, как бы в концах губ» [14, с. 503-504]. Эта связь уходит своими корнями в первобытное искусство, отличительной чертой которого был синкретизм, т.е. слитное, нерасчлененное на отдельные элементы «сочетание ритмованных, орхестических движений с песней-музыкой и элементами слова» [7, с. 155]. Ф. Ф. Зелинский подобным образом характеризовал античное искусство, которое, как писал ученый, в последующем своем развитии разделилось «на поэзию как искусство слова, музыку как искусство звука, и орхестику как искусство жеста» $[9$, с. 8], однако их генетическое родство так или иначе постоянно давало о себе знать. В частности, во французском средневековом эпосе получили широкое распространение героические поэмы - chansons de geste (песни о деяниях), сохранившие память о своем общем происхождении не только в названии, но и в характере исполнения, так как «изначально эти народные сказания предназначались для устного напевного исполнения жонглерами» [10, с. 17].

В настоящее время изучением языка тела занимается специальная наука, относящаяся к сфере невербальной семиотики, - кинесика (основоположник - американский антрополог Рэй Бердвистел). В сферу ее рассмотрения включены мимика, позы, движения тела и его частей. На стыке между членораздельной речью и семантически значимыми телодвижениями находятся так называемые голосовые жесты как элемент паравербальной речевой коммуникации (например, плач, стон и т.п.). Кроме того, в художественном тексте выделяют специфические именно для речевого высказывания словесные 
жесты, благодаря которым читатель способен зримо представить мимику и движения говорящего. Средствами их выражения могут быть отдельные слова, фразы, различные синтаксические конструкции, повторы, риторические вопросы или восклицания. В письменной речи к ним примыкают графические жесты, к которым относятся как различные способы расположения текста, имеющие знаковый характер [13], так и знаки препинания, подобные тем, что использует Андрей Белый в романе «Петербург»:

Аполлон Аполлонович, думая, что достал карандашик, вытащил из жилета костяную щеточку для ногтей и ею же собирался сделать пометку “отослать обратно по адресу”, как...

- "?.."

- "Поданы-с..." [3, с. 16].

Можно предположить, что здесь за вопросительным знаком скрывается мимический жест - приподнятые в удивлении брови как знак нарушенного ожидания при попытке персонажа написать что-то на конверте костяной щеточкой вместо карандаша. С большей долей вероятности знак препинания следует трактовать как изменившееся выражение лица персонажа, как немой вопрос, обращенный к камердинеру, прервавшем своим появлением занятие Аполлона Аполлоновича, чтобы сообщить, что карета подана.

В одном из эпизодов «Симфонии (2-й, драматической)» фигурируют части тела, являющиеся семантически нагруженными, - зубы, руки (здесь пальцы), уши, - и жест удара, который в поздней прозе Белого превратится в концептуально значимый мотив в романе «Москва под ударом»:

1. Чтоб рассеяться, он (философ. - Л.Г.) подошел к разбитому пианино. Сел на табурет и открыл крышку.

2. И стало пианино выставлять свою нижнюю челюсть, чтобы сидящий на табурете бил его по зубам.

3. И философ ударил по зубам старого друга.

4. И пошли удары за ударом. И прислуга философа затыкала уши ватой, хотя была она в кухне и все двери были затворены. 
34 Наукові записки ХНПУ ім. Г.С. Сковороди. Літературознавство, 2019, вип. 1 - 2 (91 - 92)

5. И этот ужас был зуд пальцев, и назывался он импровизацией [4, c.99-100].

Процитированный нами фрагмент строится на оппозиции жестов принятия и отторжения или соединения и разделения. С одной стороны, пианино выдвигает «нижнюю челюсть» навстречу философу, который, бьет пальцами по «зубам», т.е. по клавиатуре. С другой стороны, для выразительной визуальной демонстрации того, насколько сильное раздражающее воздействие на других персонажей оказывает громкая фортепианная игра героя, используется жест затыкания ушей. В тексте симфонии соединяются слово, звук, зрительные образы, создаваемые с помощью описания движения, жестов, мимики персонажей, и тактильные ощущения - удар и «зуд пальцев».

В жизни и творчестве Андрея Белого пластика тела (движения, позы, взгляды, мимика, жесты) занимала значительное место. Вспомним хотя бы уши сенатора Аблеухова из романа «Петербург», который, по утверждению автора, целиком является порождением «мозговой игры» главного героя, или знаменитый «берлинский фокстрот» самого Белого, описанный в воспоминаниях его современников, в частности, Марины Цветаевой, или постоянно мелькающие маски, переходящие друг в друга лики и личины, органически вписывающиеся в театрально-карнавально-балаганную культуру Серебряного века.

Предприняв анализ собственного творчества в статье «Как мы пишем. О себе как о писателе», Андрей Белый так определил место жеста среди других художественных приемов: «главенствующая особенность моих произведений есть интонация, ритм, пауза дыхания, передающие жест говорящего» [1, с. 20].

Жест как эстетическая и философская категория рассматривался в теоретических трудах Андрея Белого. Так, скрупулезно исследуя в своей до сих пор не потерявшей актуальности книге «Мастерство Гоголя» особенности организации словесного материала в гоголевских текстах, Андрей Белый называет жест как основной прием, используемый автором «Мертвых душ» для создания портретов персонажей: «Каждый тип Гоголя по Гоголю же «полон неуловимых 
особенностей»: «эти господа страшно трудны для портретов»; Гоголь же дает не портрет, а его жестовую схему...» [2, с.84-85]. Учеными неоднократно отмечалась закольцованность практически всех наблюдений Белого на себе. И на этот раз выводы писателя характеризуют в том числе и его собственный творческий метод, который отличается стремлением к тотальному синтезу - искусства и жизни, различных видов искусства, жанров, естественно-научных подходов, философии и литературы, слова и пластического знака.

В раннем творчестве Белого представлены два вида любви -Amor sacro и Amor profano (Любовь небесная и Любовь земная), что обусловлено господствующей в русском символизме идеей двоемирия. Лирический герой сборников «Золото в лазури», «Пепел», «Урна» находится в ожидании грядущего преображения мира, которое представляется как встреча поэта с Вечностью. Их соединение осмысляется по аналогии с евангельской метафорой брака Агнца (Христа) с невестой (Церковью). Подобные параллели последовательно реализованы в симфонии «Кубок метелей». Сравним.

В Откровении Иоанна Богослова о церкви говориться так: «И дано было ей облечься в виссон чистый и светлый; виссон же есть праведность святых» (Откр. 19:8). А в четвертой симфонии Белого (главка «Вторая метельная ектения») о некоем долгожданном страннике говорится: «Руки на них возлагал и в виссон облекся белый» [4, c. 295].

Оба вида любви - при том, что в случае с Amor sacro это может звучать кощунственно, и писатель сам на это указал во вступлении к «Кубку метелей» - имеют эротический оттенок и сопровождаются соответствующими жестами. В первом сборнике «Золото в лазури» Вечность утешает одинокого, отвергнутого людьми поэта:

...она,

ласкает, целует беззвучно [5, с. 23].

«Возлюбленная Вечность» улыбается лирическому герою и «манит рукой», смотрит «задумчивым взглядом», а ее призывы оцениваются им как «желанные» [5, с. 38]. В свою очередь жених в стихотворении «Последнее свидание» «с невесты не сводит осенних, 
36 Наукові записки ХНПУ ім. Г.С. Сковороди. Літературознавство, 2019, вип. 1 - 2 (91 - 92)

задумчивых глаз», а лирическая сцена сопровождается следующими жестами: склоненной позой героя, улыбкой, закрытыми глазами затаившей дыхание героини, напоминая изображение на знаменитой картине Густава Климта «Поцелуй»:

Склонился - и в воздухе ясном звучат поцелуи.

Она улыбнулась, закрыла глаза, чуть дыша [5, с. 38].

В стихотворении «Вечный зов» поэт слышит ее «напевы» («объявись - зацелую тебя...») и чувствует прикосновение («что-то снова коснулось меня») [5, с. 29]. Страстные поцелуи («Кто-то страстный тебя // зацелует!» [5, с. 34] внезапно сменяются ледяными, знаменующими приход Антихриста и сопровождаемыми «хаосом», «бредом роковым», «ужасом» и «бурей мировой»:

И на щеках заледенел

вдруг поцелуй желанных губок.

И с тяжким звоном полетел

его вина червонный кубок [5, с. 34].

В свою очередь лирический герой возлагает на голову возлюбленной венок как знак ее избранности, символ чистоты, софийного начала и в то же время как признание в любви:

Венок возложил я, любя,

из роз - и он вспыхнул огнями [5, с. 31].

В одной из своих предыдущих работ мы уже отмечали, что «в образе цветка сочетаются несколько важных в поэтической системе А. Белого тем - истины, памяти, небесной лазури, чистоты, - несущих в себе идею Софии» [8, с. 30]. Амбивалентность символики розы обусловлена тем, что с одной стороны, это прекрасный благоухающий цветок, с другой стороны, ее стебель усыпан острыми шипами, что позволяет говорить о сходстве этого образа с терновым венцом, возложенным на голову Иисуса Христа перед казнью. В лирике Белого им увенчана лирическая героиня:

Она улыбнулась, а иглы мучительных терний

ей голову сжали горячим, колючим венцом... [5, с. 39] 
Мотив «страдания-страсти» (1) обыгран Андреем Белым в четвертой симфонии «Кубок метелей». В одной из главок метель призывает главных героев, Адама Петровича и Светлову:

За руки возьмитесь, друг друга любите сегодня: уймитесь, напасти и муки, уймитесь, волнения: - страсти

Господни [4, с. 394].

Тема крестных мук сопряжена с темой чувственных переживаний, а текст литургии («Со святыми упокой Христе души раб Твоих, идеже несть болезнь, ни печаль, ни воздыхание, но жизнь безконечная») перемежается с текстом так называемого «жестокого романса», как раз переживавшего свой расцвет на рубеже XIX - XX веков. Особенно популярен был романс «Сомнение» (муз. М. Глинки на стихи Н. Кукольника) в исполнении Федора Шаляпина, воспроизведенный в тексте «Кубка метелей». Сюжетную основу жестоких романсов обычно составляли любовные страсти, мучительные переживания, ревность, разлука, соблазнение и, как следствие, трагическая гибель героя.

И тогда, погасив огни, он прошел из окна с мягкой, мягкой пургой, опадающей звездами, охватил ее стан, и она уронила головку в бурно брызнувшем снеге.

- «Мы жаа-аа-ждеем... Мы страааа-аааа-...»

«Рааа-баа

твоо-его...

идеже неесть

болезни и печали... воздыхаа-...»

- «Аа ии-стаа-мии-лаась

в раа-злуу-уу-кее» $[4$, с. 395$]$.

Произведение Белого написано по аналогии с партитурой музыкальной симфонии, в которой партии отдельных инструментов в записи на бумаге расположены последовательно, но исполняются одновременно. Подобным образом необходимо воспринимать текст «Кубка метелей», в том числе данный фрагмент, где литургия в память об усопших христианах звучит в то же время, что и «жестокий романс», а физические муки соединяются с духовными страданиями 
38 Наукові записки ХНПУ ім. Г.С. Сковороди. Літературознавство, 2019, вип. 1 - 2 (91 - 92)

с помощью слова-модератора «страсти», употребленного в различных грамматических формах.

Противоречивая реакция лирического героя выражается с помощью голосовых жестов - он в одно и то же время и смеется, и плачет. Диапазон его переживаний, приходящихся на так называемый «период зорь», включает самые разнообразные оттенки, начиная с «пирных восторгов» и заканчивая «восторженно-пьяной печалью», в том числе и повторяющийся мотив смеха-плача:

Смеюсь - и мой смех серебрист,

и плачу сквозь смех поневоле.

Зачем этот воздух лучист?

Зачем светозарен... до боли? [5, с. 31].

К наиболее частотным в лирике Белого относятся противоположно направленные жесты: воздетые к небесам руки и склоненное к земле тело, которые встречаются и в эротическом контексте:

Обращенный лицом к старине, я склонился с мольбою за 5 ко мне

золотых, лучезарных дерев [5, с. 29].

Подобным жестом завершается «Кубок метелей»: «Многокрестное кладбище, терзаемое порывом, страстным гласом стенало, в любовной ширило пытке свои лампады - огневые, янтарные очи, - пурговыми лопастями свеиваясь, точно в час брачный свеивалась фата, истерзанная невестой; оно потрясало руками - десятками крестов, к Нему тянулось старинным томлением» [4, с. 418].

По воспоминаниям современников, выступления самого Андрея Белого сопровождались весьма эмоциональной жестикуляцией. Именно таким - с воздетыми руками, «то притоптывающего, то подымающего руки, точно подтягиваясь на трапеции, то выбрасывающего их, словно от чего-то отшатываясь»-впервые увидел писателя Н. Валентинов в Москве 1905 года [6, с. 12], и таким же Белый изображен на одном из наиболее известных прижизненных портретов работы Е.С. Кругликовой.

Таким образом, в ранних произведениях Андрея Белого используются различные типы жестов - словесные, голосовые, а также 
соответствующие определенным жестам графические знаки. Они являются органической частью лирического дневника, сопровождая отношения героя-поэта и его возлюбленной Вечности, данные в двух соположенных планах - Amor sacro и Amor profano. Система эротических жестов организована, во-первых, по принципу зеркальных отражений, воплощая символистские представления о том, что мир дольний является подобием, пусть иллюзорным и несовершенным, мира горнего. Во-вторых, жесты выполняют две основные функции, а именно, помогают передать внутреннее состояние героев, а также служат средством коммуникации между ними. На выраженные с их помощью вопрос, приглашение, обращение обычно следует ответ. В-третьих, жесты в произведениях Белого часто омонимичны, что в случае с эротическими жестами приводит к размытию границ между телесным и духовным, земным и божественным.

\section{Примечания}

(1) Ср. с мотивом «радость-страданье» у А. Блока, в частности в его драме «Роза и Крест».

\section{Литература}

1. Белый А. Как мы пишем. О себе как о писателе. Андрей Белый. Проблемы творчества: Статьи. Воспоминания. Публикации. М.: Сов. писатель, 1988. С. 8-24.

2. Белый А. Мастерство Гоголя. Исследование. М.; Л.: ОГИЗ, 1934. XV, $322 \mathrm{c.}$

3. Белый А. Петербург. М.: Наука, 1981. 696 с.

4. Белый А. Симфонии. Л.: Худож. литература, 1991. 526 с.

5. Белый А. Собрание сочинений. Стихотворения и поэмы. М.: Республика, 1994. 559 с.

6. Валентинов Н. Два года с символистами. The Hoover Institution on War, Revolution and Peace. Stanford University, Stanford, California. 1969. $241 \mathrm{c}$.

7. Веселовский А.Н. Историческая поэтика. М.: Высш. шк., 1989. 406 с.

8. Гармаш Л.В. Образ Софии в ранней прозе Андрея Белого. Русская филология. Укр. вестник. Харьков, 2002. № 1-2 (21) С. 29-31.

9. Зелинский Ф.Ф. История античной культуры. 2-е изд. СПб.: Марс, $1995.380 \mathrm{c}$. 
40 Наукові записки ХНПУ ім. Г.С. Сковороди. Літературознавство, 2019, вип. 1 - 2 (91 - 92)

10. Косиков Г. К. Собрание сочинений. Т. 1: Французская литература. М.: Центр книги Рудомино, 2011. 488 с.

11. Кухта А.И. Языковая экспрессивность в художественном тексте. Межкультурная коммуникация в современном обществе: мат-лы II Междунар. науч. конф. «Межкультурная коммуникация в современном обществе». Саранск, 2011. «Язык. Культура. Общество» Вып. 3. http://yazik. englishleo.ru/2011-05.php.

12. Масленникова О.Н. Пластический жест в прозе Андрея Белого. Вопросы Онтологической поэтики. Потаенная литература. Иваново, 1998. C. $109-114$.

13. Толоконникова С.Ю. К вопросу о метре и ритме прозаического текста: роман Андрея Белого «Крещеный китаец». Русская филология. Ученые записки Смоленского гос. пед. ин-та. Смоленск, 1996. С. 161-164.

14. Тынянов Ю. Архаисты и новаторы. Л.: Прибой, 1929. 598 с.

15. Фасмер М. Этимологический словарь русского языка. В 4 т. Т. 2. Е Муж / М. Фасмер; пер. с нем. и доп. О.Н. Трубачёва; под ред. и с предисл. Б.А. Ларина. изд. 2-е, стер. М.: Прогресс, 1986. 672 с.

\section{References}

1. Bely A. "Kak my pishem. O sebe kak o pisatele [As we write. About me as a writer]." Andrey Bely. Problems of creativity: Articles. Memories. Publications. Moscow: Sov. writer, 1988. P. 8-24.

2. Bely A. Masterstvo Gogolya. Issledovanie. [Mastery of Gogol. Study]. Moscow; Leningrad: OGIZ, 1934. XV, 322 p.

3. Bely A. Petersburg. Moscow: Nauka, 1981. 696 p.

4. Bely A. Symphonies. Leningrad: Hudozh. lit., 1991. 526 p.

5. Bely A. Sobranie sochinenij. Stihotvoreniya i poemy [Collected Works. Poems]. Moscow: Republic, 1994. 555 s.

6. Valentinov N. Dva goda s simvolistami. [Two Years with Symbolists]. Stanford University, Stanford, California. 1969. 241 p.

7. Veselovsky A.N. Istoricheskaya poetika. [Historical poetics]. Moscow: High school, 1989. $406 \mathrm{p}$.

8. Garmash L. "Obraz Sofii v rannej proze Andreya Belogo [Image of Sofia in the early prose of Andrei Bely]." Russian Philology. Ukr. messenger. Kharkov, 2002. No. 1-2 (21). P. 29-31.

9. Zelinsky F.F. Istoriya antichnoj kul'tury [The history of ancient culture]. 2nd ed. St. Petersburg: Mars, 1995. 380 p.

10. Kosikov G.K. Sobranie sochinenij [Collected Works]. Vol. 1: French literature. Moscow: Rudomino Book Center, 2011. 488 p. 
11. Kukhta A.I. "Yazykovaya ekspressivnost' v hudozhestvennom tekste [Language expressivity in a literary text]." Intercultural communication in modern society: materials of the II Intern. scientific conf. "Intercultural communication in modern society." Saransk, 2011. "Language. The culture. Society". Vol. 3. http: //yazik.englishleo.ru/2011-05.php.

12. Maslennikova O.N. "Plasticheskij zhest v proze Andreya Belogo [Plastic gesture in Andrei Bely prose]." Issues of Ontological poetics. Hidden literature. Ivanovo, 1998. P. 109-114.

13. Tolokonnikova $\mathrm{S}$. Yu. "K voprosu o metre i ritme prozaicheskogo teksta: roman Andreya Belogo «Kreshchenyj kitaec» [On the issue of the meter and rhythm of a prosaic text: Andrei Bely's novel «The Baptized Chinese»]." Russian Philology. Scientific notes of Smolensk state pedagogical institute. Smolensk, 1996. P. 161-164.

14. Tynyanov Yu. Arhaisty i novatory [Archaists and innovators]. Leningrad: Surf, 1929. 598 p.

15. Fasmer M. Etimologicheskij slovar' russkogo yazyka [Etymological Dictionary of the Russian Language]. In 4 vol. Vol. 2. E - M. $2^{\text {nd }}$ ed. Moscow: Progress, 1986. $672 \mathrm{p}$.

\section{Анотація}

\section{Л.В. Гармаш. Еротичні жести в поезії і літературних симфоніях} Андрія Бслого: від «Золота в блакиті» до «Кубку заметілі»

У роботі зроблено аналіз еротичних жестів в ліриці і в симфоніях Андрія Бєлого як структурно значущих елементів художнього тексту, які розглядаються в контексті творчості одного 3 найбільш відомих російських символістів. Встановлено кореляти між жестом як поетичним прийомом i світоглядними установками автора «Золота в блакиті» і літературних симфоній.

Пластика тіла (руху, пози, погляди, міміка, жести) займала значне місце в житті і творчості письменника, який використовував для передачі жесту найрізноманітніші засоби (інтонацію, ритм, паузи тощо). У ранніх творах Андрія Бєлого в достатку зустрічаються різні типи жестів - словесні, голосові, а також відповідні певним жестам графічні знаки. Жести є органічною частиною ліричного щоденника, супроводжуючи відносини героя-поета і його коханої Вічності, дані в двох збігання планах - Amor sacro i Amor profano. Ці два плани організують просторову і смислове вертикаль, визначальну спрямованість жестів в симфоніях і ліриці поета. Система еротичних жестів організована за принципом дзеркальних відображень, втілюючи символістські уявлення про те, що світ земний є подобою, нехай ілюзорним і недосконалим, світу горішнього. Паралелі, що виникають між двома 
видами любові, визначають амбівалентний характер жестів, їхню одночасну наявність у двох планах буття, що припускає поєднання в одному жесті еротичних і містичних (релігійних) конотацій. У ранній творчості Андрія Бєлого жести виконують дві основні функції: вони допомагають передати внутрішній стан героїв та служать засобом комунікації між ними. Жестові питання, запрошення, звернення зазвичай мають відповідь. Жести у Бєлого часто омонімічні, що у випадку з еротичними жестами призводить до розмиття кордонів між тілесним і духовним, земним і божественним первнями.

Ключові слова: Андрій Бєлий, еротичний жест, словесний жест, голосовий жест, графічний знак, символізм.

\section{Аннотация}

Л.В. Гармаш Эротические жесты в поэзии и литературных симфониях Андрея Белого: от «Золота в лазури» к «Кубку метелей»

В работе предпринят анализ эротических жестов в лирике и в симфониях Андрея Белого как структурно значимых элементов художественного текста, которые рассматриваются в контексте творчества одного из наиболее известных русских символистов. Установлены корреляты между жестом как поэтическим приемом и мировоззренческими установками автора «Золота в лазури» и литературных симфоний.

Пластика тела (движения, позы, взгляды, мимика, жесты) занимала значительное место в жизни и творчестве писателя, который использовал для передачи жеста самые разные средства (интонацию, ритм, паузы и т.д.). В ранних произведениях Андрея Белого в изобилии встречаются различные типы жестов - словесные, голосовые, а также соответствующие определенным жестам графические знаки. Жесты являются органической частью лирического дневника, сопровождая отношения героя-поэта и его возлюбленной Вечности, данные в двух соположенных планах - Amor sacro и Amor profano. Эти два плана организуют пространственную и смысловую вертикаль, определяющую направленность жестов в симфониях и лирике поэта. Система эротических жестов организована по принципу зеркальных отражений, воплощая символистские представления о том, что мир дольний является подобием, пусть иллюзорным и несовершенным, мира горнего. Параллели, возникающие между двумя видами любви, определяют амбивалентный характер жестов, их двуплановость, подразумевающую соединение в одном жесте эротических и мистических (религиозных) коннотаций. В раннем творчестве Андрея Белого жесты выполняют две основные функции, а именно, помогают передать внутреннее состояние героев, а также служат средством коммуникации между ними. На выраженные с их помощью вопрос, приглашение, обращение обычно следует ответ. Жесты в 
произведениях Белого часто омонимичны, что в случае с эротическими жестами приводит к размытию границ между телесным и духовным, земным и божественным.

Ключевые слова: Андрей Белый, эротический жест, словесный жест, голосовой жест, графический знак, символизм.

\section{Summary}

\section{L.V. Harmash. Erotic Gestures in Poetry and Literary Symphonies by} Andrei Bely: from "Gold in Azure" to "Goblet of Blizzards"

The paper analyzes the erotic gestures in Andrei Bely's lyrics and symphonies as structurally significant elements of a literary text, which are considered in the context of the work of one of the most famous Russian symbolists. Correlates between the gesture as a poetic device and the philosophical attitudes of the author of "Gold in Azure" and literary symphonies are established.

Body plastic (movements, postures, looks, facial expressions, gestures) occupied a significant place in the life and work of the writer, who used a variety of means to convey a gesture (intonation, rhythm, pauses, etc.). In the early works of Andrei Bely, various types of gestures are found in abundance: verbal, voice and graphic signs correspond to certain gestures. Gestures are an organic part of the lyric diary, accompanying the relationship of the hero-poet and his beloved Eternity, given in two paired plans - Amor sacro and Amor profano. These two plans organize the spatial and semantic vertical, which determines the direction of gestures in the poet's symphonies and lyrics. The system of erotic gestures is organized according to the principle of mirror reflections, embodying the symbolist ideas that the low world is a likeness, albeit illusory and imperfect, of the high world. The parallels that arise between the two types of love determine the ambivalence of gestures, their two-dimensional nature, implying a combination of erotic and mystical (religious) connotations in one gesture. In the early work of Andrei Bely, gestures perform two main functions, namely, they help to convey the internal state of the characters, and also serve as a means of communication between them. The question, invitation, appeal expressed with gestures is usually followed by an answer. Gestures are often homonymous, which in the case of erotic gestures leads to blurring of the boundaries between the physical and the spiritual, the earthly and the divine spheres.

Keywords: Andrei Bely, erotic gesture, verbal gesture, voice gesture, graphic sign, symbolism. 
44 Наукові записки ХНПУ ім. Г.С. Сковороди. Літературознавство, 2019, вип. 1 - 2 (91 - 92)

\section{Інформація про автора}

Гармаш Людмила Вікторівна - доктор філологічних наук, доцент кафедри світової літератури Харківського національного педагогічного університету імені Г.С. Сковороди; вул. Валентинівська, 2, м. Харків, 61168, Україна; http://orcid.org/0000-0002-8638-3860 